\title{
Short communication: The preruminant calf as a model for characterizing the effects of vitamin $D$ status in the neonate ${ }^{1}$
}

\author{
B. J. Nonnecke, ${ }^{* 2}$ T. A. Reinhardt, ${ }^{*}$ and W. R. Waters \\ ${ }^{*}$ Periparturient Diseases of Cattle Research Unit, and \\ †Bacterial Diseases of Livestock Research Unit, USDA-ARS National Animal Disease Center, Ames, IA 50010-0070
}

\begin{abstract}
The objective of this study was to evaluate the feasibility of using the preruminant dairy calf as a model for evaluating effects of vitamin $\mathrm{D}$ status in the neonate. Because the newborn calf can be sustained during the first weeks of life solely on a fluid diet having a defined composition, has documented nutritional requirements, and is minimally affected by repeated samplings of peripheral blood, it has the potential to serve as a model for characterizing nutrient-specific effects on the growth and health of the neonate. Colostrum-fed Holstein bull calves $(n=13)$ entered the trial at approximately $4 \mathrm{~d}$ of age. All calves were fed a custom-formulated milk replacer devoid of vitamin D. Plasma 25-hydroxyvitamin $\mathrm{D}_{3}$ concentrations in all calves were determined on a regular basis beginning at $\mathrm{d} 0$. Using this information, low- and high-status groups of calves were established by subcutaneous administration of 25-hydroxyvitamin $\mathrm{D}_{3}$. To maintain targeted plasma 25-hydroxyvitamin $\mathrm{D}_{3}$ concentrations in low $(<30 \mathrm{ng} / \mathrm{mL})$ and high $(>60 \mathrm{ng} /$ $\mathrm{mL}$ ) vitamin $\mathrm{D}$-status calves, low-status calves $(\mathrm{n}=6)$ received a total of $8,600 \mathrm{IU}(2,225 \mathrm{IU} /$ wk) of vitamin D during the experimental period and high-status calves $(\mathrm{n}=7)$ received 54,000 IU $(13,500 \mathrm{IU} / \mathrm{wk})$. Concentrations of 25-hydroxyvitamin $\mathrm{D}_{3}$ in low-status calves averaged $27 \mathrm{ng} / \mathrm{mL}$, compared with $78 \mathrm{ng} / \mathrm{mL}$ in highstatus calves, and were less at all sampling times from d 7 to d 28. Concentrations of 1,25-dihydroxyvitamin $\mathrm{D}_{3}$ and 25-hydroxyvitamin $\mathrm{D}_{3}$ were not correlated. Calcium, magnesium, and phosphorous concentrations were unaffected by 25-hydroxyvitamin $\mathrm{D}_{3}$ administration; however, plasma calcium and 1,25-dihydroxyvitamin $\mathrm{D}_{3}$ concentrations were correlated. Calcium and magnesium concentrations decreased with age but remained within normal ranges for dairy cattle. These
\end{abstract}

\footnotetext{
Received June 12, 2009.

Accepted July 28, 2009

${ }^{1}$ Names are necessary to report factually on available data; however, the USDA neither guarantees nor warrants the standard of the product, and the use of the name by the USDA implies no approval of the product to the exclusion of others that may also be suitable.

${ }^{2}$ Corresponding author: brian.nonnecke@ars.usda.gov
}

results indicate that it is possible to predictably control vitamin D status over a 28-d period and suggest that the preruminant calf might be useful as a model for studying effects of vitamin D on growth, development, and immune function in the neonate.

Key words: preruminant calf, vitamin D status, neonatal nutrition

Vitamin D plays a pivotal role in calcium homeostasis, cell differentiation and proliferation, and innate and adaptive immune function (van Etten et al., 2008). Vitamin $\mathrm{D}$ is derived from 2 sources: dietary intake [vitamin $\mathrm{D}_{2}$ (ergocalciferol) from plant sources or $\mathrm{D}_{3}$ (cholecalciferol) from animal sources] and the conversion of 7-dehydrocholesterol to cholecalciferol in the skin, a reaction catalyzed by UV light. In the absence of sufficient sun exposure for dermal conversion, vitamin D becomes an essential nutrient. At body temperature, cholecalciferol spontaneously converts to vitamin $\mathrm{D}_{3}$. Vitamin D provided in the diet or produced in the skin is rapidly transported to and sequestered by the liver, where it is available for conversion to 25-hydroxyvitamin $\mathrm{D}\left[\mathbf{2 5}(\mathbf{O H}) \mathbf{D}_{3}\right]$. This metabolite in association with vitamin $\mathrm{D}$ binding protein is the predominant circulating form and is considered the best indicator of vitamin D status (Horst et al., 1994; Looker et al., $2008)$. In hypocalcemic states, $25(\mathrm{OH}) \mathrm{D}_{3}$ is hydroxylated to 1,25 -dihydroxyvitamin $\mathrm{D}_{3}\left[\mathbf{1}, \mathbf{2 5}(\mathbf{O H})_{2} \mathbf{D}_{3}\right]$ in the kidney. As the major mediator of biological activity of vitamin $\mathrm{D}$, this metabolite acts to increase active transport of calcium and phosphorous across intestinal epithelium and potentiates the action of parathyroid hormone to increase bone calcium resorption.

Historically, vitamin D deficiency has been associated with osteomalacia, osteopenia, osteoporosis, and muscle weakness. More recently, deficiency in humans has been linked to increased risk of cancer, autoimmune disease, cardiovascular disease, and infectious disease (Holick, 2007; Norman, 2008). In humans, normal circulating concentrations have been defined as 22 to $30 \mathrm{ng} / \mathrm{mL}$ for $25(\mathrm{OH}) \mathrm{D}_{3}$ and 25 to $34 \mathrm{pg} / \mathrm{mL}$ for $1,25(\mathrm{OH})_{2} \mathrm{D}_{3}$ (Salle et al., 2000). However, recent evidence suggests that in humans, greater plasma $25(\mathrm{OH}) \mathrm{D}_{3}$ concentrations 
might be necessary to ensure sufficiency (Hollis, 2005). Plasma $25(\mathrm{OH}) \mathrm{D}_{3}$ at $>32 \mathrm{ng} / \mathrm{mL}$ enhances innate immunity in humans (Holick, 2007), a level exceeding the amount necessary to ensure calcium homeostasis. In healthy dairy cows, plasma $25(\mathrm{OH}) \mathrm{D}_{3}$ concentrations range from 20 to $50 \mathrm{ng} / \mathrm{mL}$. Values less than $5 \mathrm{ng} /$ $\mathrm{mL}$ are considered indicative of vitamin $\mathrm{D}$ deficiency, whereas concentrations in excess of 200 to $300 \mathrm{ng} /$ $\mathrm{mL}$ are indicative of vitamin $\mathrm{D}$ toxicosis (Horst et al., 1994). It is not clear if these adult values apply to the newborn calf.

The current recommended vitamin $\mathrm{D}$ requirement (NRC, 2001) for preruminant calves is $318 \mathrm{IU} / \mathrm{d}$ for a $45-\mathrm{kg}$ calf fed $0.53 \mathrm{~kg}$ of $\mathrm{DM} / \mathrm{d}$. Commercial milk replacers typically provide the calf $2,650 \mathrm{IU} / \mathrm{d}$, substantially more vitamin D than the NRC recommendation. Justification for the current NRC recommendation or evidence supporting the substantially greater amounts in commercial milk replacers is limited. In addition, data regarding cutoffs of plasma $25(\mathrm{OH}) \mathrm{D}_{3}$ that define the lower limit of adequacy or sufficiency in the preruminant calf are sparse. Given recent evidence in other species suggesting vitamin D concentrations not previously considered representative of deficiency might be linked to nonskeletal diseases (Holick, 2007), reexamination of the effects of vitamin D supplementation on the neonate might be warranted.

The purpose of the current study was to develop a method for manipulating, in consistent fashion, the vitamin D status of the milk replacer-fed calf. Successful demonstration of this approach would not only yield new information regarding vitamin D status in the preruminant calf but also might provide a suitable animal model for evaluating the effects of vitamin $\mathrm{D}$ on the growth, development, and health of the neonate.

Animal-related procedures were approved by the Animal Care and Use Committee of the National Animal Disease Center (NADC), Ames, Iowa. Holstein bull calves $(\mathrm{n}=13)$ from a single Wisconsin dairy herd were given $4 \mathrm{~L}$ of colostrum within the first $6 \mathrm{~h}$ after birth. Navels were dipped in iodine, and an Escherichia coli vaccine (Genecol-99, Schering-Plough Animal Health, Union, NJ) was administered orally at birth. At less than $4 \mathrm{~d}$ of age, calves were transported to NADC where they were housed individually in elevated pens (1.52 m long $\times 0.92 \mathrm{~m}$ wide $\times 0.92 \mathrm{~m}$ high $)$ in a calfspecific barn with temperatures maintained between 15 and $18^{\circ} \mathrm{C}$. Each calf was given $2 \mathrm{~mL}$ of iron dextran $(100$ $\mathrm{mg} / \mathrm{mL}$, AmTech, Phoenix Scientific, Inc., St. Joseph, $\mathrm{MO}$ ) intramuscularly, a 2.5 -mL solution of sodium selenite $(2.19 \mathrm{mg} / \mathrm{mL})$ and $\alpha$-tocopherol $(50 \mathrm{mg} / \mathrm{mL}$; BoSe, Schering-Plough Animal Health) intramuscularly, and $2 \mathrm{~mL}$ of a vitamin B complex (Phoenix Scientific, Inc.) subcutaneously. At the time of arrival, calves were of-
Table 1. Composition of milk replacer ${ }^{1}$ fed to all calves during the 28-d experimental period

\begin{tabular}{llc}
\hline Component & Unit & Analysis \\
\hline CP & $\%$ of DM & 28.09 \\
Fat & $\%$ of DM & 20.05 \\
Lactose & $\%$ of DM & 30.00 \\
Vitamin $\mathrm{D}_{3}$ & $\mathrm{IU} / \mathrm{kg}$ & 0.00 \\
Vitamin A & $\mathrm{IU} / \mathrm{kg}$ & 13,608 \\
Vitamin E & $\mathrm{IU} / \mathrm{kg}$ & 90.80 \\
Calcium & $\%$ of DM & 0.75 \\
Phosphorous & $\%$ of DM & 0.06 \\
Magnesium & $\%$ of DM & 0.11 \\
\hline
\end{tabular}

${ }^{1}$ Manufactured by Animix LCC, Juneau, WI. Not all components are listed.

fered Enterolyte (Pfizer, Exton, PA) mixed in warm water following the manufacturer's directions.

Within $24 \mathrm{~h}$ after arrival, calves were weighed and assigned randomly to 2 treatment groups that would represent low $\left[15-25 \mathrm{ng}\right.$ of $25(\mathrm{OH}) \mathrm{D}_{3} / \mathrm{mL}$ of plasma, $\mathrm{n}$ $=6]$ and high vitamin D status [55-65 ng of $25(\mathrm{OH})$ $\mathrm{D}_{3} / \mathrm{mL}$ of plasma, $\left.\mathrm{n}=7\right]$. During the $28-\mathrm{d}$ study, all calves were fed twice daily $0.34 \mathrm{~kg}$ of a $28 \% \mathrm{CP}, 20 \%$ fat, all-milk protein milk replacer (Table 1, Animix LLC, Juneau, WI) devoid of exogenous vitamin D and reconstituted to $15 \%$ dry matter. Plasma $25(\mathrm{OH}) \mathrm{D}_{3}$ concentrations in all calves were determined at regular intervals, beginning at $\mathrm{d} 0$. Based on these data and calf BW, low- and high-status groups of calves were established by subcutaneous administration of $25(\mathrm{OH})$ $\mathrm{D}_{3}$ (range: 75 to $500 \mathrm{mg} / \mathrm{mL}$ in reagent-grade ethanol, $1 \mathrm{~mL}$ total/administration). Low-status calves received, on average, 8,600 IU of vitamin D during the experimental period, and high-status calves received 54,000 IU.

Concentrations of $25(\mathrm{OH}) \mathrm{D}_{3}$ and $1,25(\mathrm{OH})_{2} \mathrm{D}_{3}$ in plasma and milk replacer were quantified using radioimmunoassay as described by Hollis et al. (1993 and 1996, respectively). Serum calcium and magnesium concentrations were determined by atomic absorption spectrometry (Perkin-Elmer Corp, Norwalk, CT) as described previously (Waldron et al., 2003). Serum phosphorous $\left(\mathrm{PO}_{4}\right)$ was measured colorimetrically using a procedure modified from Parekh and Jung (1970) and validated in our laboratory. Briefly, serum $(125 \mu \mathrm{L})$ was precipitated by acidification with $1 \mathrm{~mL}$ of molybdictrichloroacetic acid solution. After $5 \mathrm{~min}$, the solution was centrifuged $(1,000 \times g)$, and $100 \mu \mathrm{L}$ of supernatant was transferred in duplicate to 96-well microplates (Costar, Corning Inc., Acton, MA). Finally, $150 \mu \mathrm{L}$ of $p$-phenylenediamine reagent ( $1 \mathrm{~g}$ of $p$-phenylenediamine dihydrochloride in $100 \mathrm{~mL}$ of $5 \% \mathrm{Na}_{2} \mathrm{~S}_{2} \mathrm{O}_{5}$ solution) was added to all wells. Plates were incubated for $20 \mathrm{~min}$ at room temperature. Phosphorous was determined at a wavelength between 690 and $560 \mathrm{~nm}$ using a Thermo 
Max tunable, microplate-reader spectrophotometer (Molecular Devices, Sunnyvale, CA).

Data used in the final analyses were from vitamin $\mathrm{D}$ and mineral assays performed en bloc at the conclusion of the study. Data were analyzed as a completely randomized design using Statview software (version 5.0, SAS Institute, Inc., Cary, NC). Calf served as the experimental unit in the analysis of all data. Vitamin and mineral concentrations were analyzed as a split-plot with repeated-measures ANOVA. The model included the fixed effects of treatments, time (day after initiation of treatments), and treatment $\times$ time interaction, with calf included in the model as the random effect. Fisher's protected least significant difference was applied when treatment, time, or treatment $\times$ time effects $(P<0.05)$ were detected by the model. Pearson product-moment correlations were computed between plasma concentrations of $25(\mathrm{OH}) \mathrm{D}_{3}, 1,25(\mathrm{OH})_{2} \mathrm{D}_{3}, \mathrm{Ca}$, $\mathrm{PO}_{4}$, and $\mathrm{Mg}$. Correlations were judged significant at $P$ $<0.01$ with $\mathrm{r}>0.40$.

Results demonstrate that by adjusting the amount of $25(\mathrm{OH}) \mathrm{D}_{3}$ administered subcutaneously using data from periodic analysis of plasma $25(\mathrm{OH}) \mathrm{D}_{3}$ concentrations, it is possible to establish groups of calves representing low and high vitamin D status (Figure 1a). Parenteral administration of vitamin $\mathrm{D}$ provides a degree of precision not afforded by feeding milk replacer with varying amounts of vitamin $\mathrm{D}$. Using this approach, treatment $(P<0.001)$ and time $(P<0.0001)$ effects, as well as treatment $\times$ time interaction $(P<0.01)$, were significant for plasma $25(\mathrm{OH}) \mathrm{D}_{3}$ concentrations. At the beginning of the trial $(\mathrm{d} 0), 25(\mathrm{OH}) \mathrm{D}_{3}$ concentrations in both groups were not different $(P>0.05)$ and averaged $25 \mathrm{ng} / \mathrm{mL}$, a value comparable to $25(\mathrm{OH}) \mathrm{D}_{3}$ concentrations observed in newborn colostrum-fed and colostrum-deprived calves sampled $7 \mathrm{~h}$ after birth (Rajaraman et al., 1997). The $25(\mathrm{OH}) \mathrm{D}_{3}$ concentrations in the high-status group increased $(P<0.05)$ between $\mathrm{d}$ 0 and $\mathrm{d} 7$ and were greater $(P<0.05)$ than that in the low-status group from d 7 through d 28. On d 7, 21, 25, and 28 , concentrations exceeded $90 \mathrm{ng} / \mathrm{mL}$, more than 3 -fold greater than concentrations in low-status calves, and exceeded the maximal concentrations observed in standard $(87 \mathrm{ng} / \mathrm{mL})$ or intensified $(89 \mathrm{ng} / \mathrm{mL})$ milk replacer-fed calves (Nonnecke et al., 2007). These concentrations were achieved by administering, on average, a total of 54,000 IU of vitamin $\mathrm{D} /$ calf during the 28 -d study. In contrast, $25(\mathrm{OH}) \mathrm{D}_{3}$ concentrations in the lowstatus group did not change significantly from d 0 to d 25 and ranged from 21 to $29 \mathrm{ng} / \mathrm{mL}$. To maintain these concentrations, each calf in the low-status group received a total of $8,600 \mathrm{IU}$ of vitamin $\mathrm{D}$ during the trial. As a comparison, $25(\mathrm{OH}) \mathrm{D}_{3}$ in calves fed either whole or skimmed milk declined progressively to approximately
10 to $12 \mathrm{ng} / \mathrm{mL}$ by $7 \mathrm{~d}$ of age (Rajaraman et al., 1997), suggesting that the $25(\mathrm{OH}) \mathrm{D}_{3}$ concentrations observed in low- and high-status groups in the current study exceeded values that might be expected in calves fed colostrum and milk only. The markedly lower plasma $25(\mathrm{OH}) \mathrm{D}_{3}$ concentrations in calves fed colostrum and milk versus those in calves in the current study and those fed commercial milk replacers (Nonnecke et al., 2007) suggest that the amount of vitamin D added to calf milk replacers needs to be reevaluated.

Because $1,25(\mathrm{OH})_{2} \mathrm{D}_{3}$ is the principal mediator of the physiologic effects of vitamin $\mathrm{D}$, plasma concentrations of $1,25(\mathrm{OH})_{2} \mathrm{D}_{3}$ and $\mathrm{Ca}, \mathrm{Mg}$, and $\mathrm{PO}_{4}$ were also evaluated. It is generally recognized that blood $1,25(\mathrm{OH})_{2} \mathrm{D}_{3}$ concentrations change in response to alterations in blood macromineral concentrations rather than blood concentrations of the pro-hormone, $25(\mathrm{OH})$ $\mathrm{D}_{3}$. A classic example in dairy cattle is the progressive increase in $1,25(\mathrm{OH})_{2} \mathrm{D}_{3}$ concentrations from $<20$ $\mathrm{pg} / \mathrm{mL}$ in the nonpregnant animal to 20 to $50 \mathrm{pg} / \mathrm{mL}$ in late gestation and $>100 \mathrm{pg} / \mathrm{mL}$ at the initiation of lactation in response to increased $\mathrm{Ca}$ demand. Once $\mathrm{Ca}$ homeostasis is reestablished during lactation, concentrations drop to 0 to $20 \mathrm{pg} / \mathrm{mL}$ (Reinhardt et al., 1988). Plasma $1,25(\mathrm{OH})_{2} \mathrm{D}_{3}$ concentrations in low- and high-status vitamin D calves are shown in Figure 1b. The treatment $\times$ time interaction was not significant $(P=0.91)$ for this variable, suggesting that parenteral administration of $25(\mathrm{OH}) \mathrm{D}_{3}$, although influencing blood $25(\mathrm{OH}) \mathrm{D}_{3}$ concentrations, did not affect $1,25(\mathrm{OH})_{2} \mathrm{D}_{3}$ concentrations. Results from the correlation analysis indicating that the association between plasma $25(\mathrm{OH})$ $\mathrm{D}_{3}$ and $1,25(\mathrm{OH})_{2} \mathrm{D}_{3}$ concentrations was not significant $(\mathrm{r}=0.196, P=0.53, \mathrm{n}=115)$ confirmed this assumption. Blood $1,25(\mathrm{OH})_{2} \mathrm{D}_{3}$ concentrations in all calves were greater $(P<0.01)$ at $\mathrm{d} 0$ than at any subsequent time during the 28-d study. During this period, concentrations ranged from $154 \mathrm{pg} / \mathrm{mL}$ on d 0 to $56 \mathrm{pg} /$ $\mathrm{mL}$ on $\mathrm{d} 21$. These results are similar to those reported by Rajaraman et al. (1997) indicating an age-related decrease in plasma $1,25(\mathrm{OH})_{2} \mathrm{D}_{3}$ concentrations in preruminant calves beginning at approximately 2 to 4 d of age. Interestingly, several reports have indicated that circulating $1,25(\mathrm{OH})_{2} \mathrm{D}_{3}$ levels in calves (Naito et al., 1983; Rajaraman et al., 1997) and human infants (Barlet et al., 1981) increase significantly within the first $48 \mathrm{~h}$ postpartum, possibly because of synthesis of $1,25(\mathrm{OH})_{2} \mathrm{D}_{3}$ as a prerequisite for intestinal absorption of calcium and phosphorous (Steichen et al., 1980). Because calves in the current study were more than $2 \mathrm{~d}$ of age at the beginning of this study, this early increase in $1,25(\mathrm{OH}){ }_{2} \mathrm{D}_{3}$ was not seen.

Calcium, $\mathrm{Mg}$, and $\mathrm{PO}_{4}$ are essential for normal function of many tissues and physiologic processes in dairy 

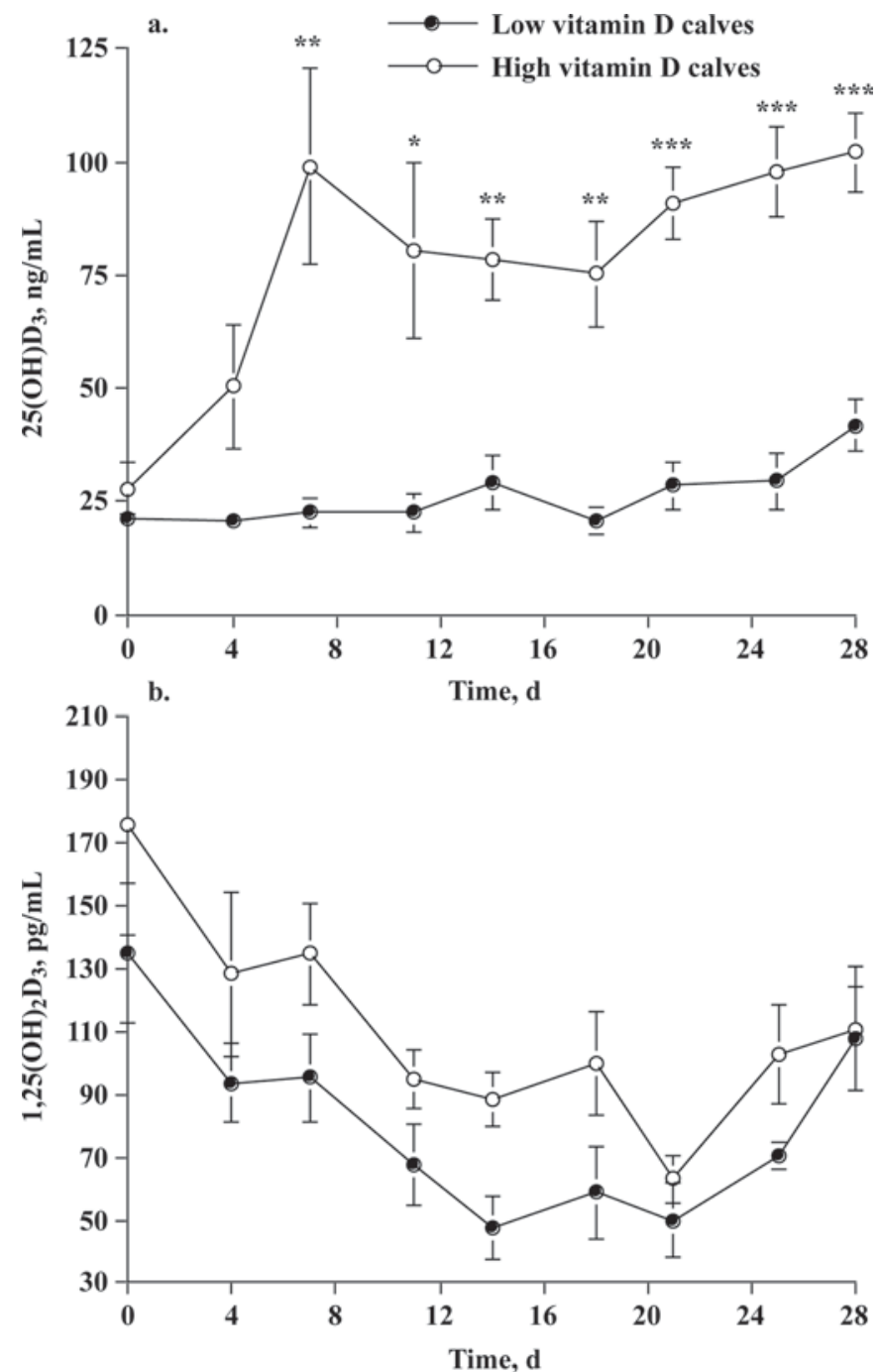

Figure 1. Plasma 25-hydroxyvitamin $\mathrm{D}_{3}\left[25(\mathrm{OH}) \mathrm{D}_{3}\right.$; panel a] and 1,25-dihydroxyvitamin $\mathrm{D}_{3}\left[1,25(\mathrm{OH})_{2} \mathrm{D}_{3}\right.$; panel b] concentrations in preruminant calves administered $25(\mathrm{OH}) \mathrm{D}_{3}$ subcutaneously at varying intervals during a 28-d study period with the goal of establishing a low vitamin $\mathrm{D}$ status group $(\mathrm{n}=6$ calves) and high vitamin $\mathrm{D}$ status ( $\mathrm{n}$ $=7)$ group. Mean plasma $25(\mathrm{OH}) \mathrm{D}_{3}$ concentrations in low- $(27 \mathrm{ng} /$ $\mathrm{mL})$ and high-status $(78 \mathrm{ng} / \mathrm{mL})$ groups differed $(P<0.05)$ during the period. Treatment means that differed at a specific time are indicated by $* P<0.05,{ }^{* *} P<0.01$, and ${ }^{* * *} P<0.001$.

cattle (Reinhardt et al., 1988; Goff, 2004). Body pools of these macrominerals are regulated by several hormones, including $1,25(\mathrm{OH})_{2} \mathrm{D}_{3}$. Although mean plasma $25(\mathrm{OH})$ $\mathrm{D}_{3}$ concentrations in low- and high-status calves differed markedly from d 7 through d 28 as a consequence of repeated administration of $1,25(\mathrm{OH})_{2} \mathrm{D}_{3}$ (Figure 1a), circulating $\mathrm{Ca}$ (Figure 2a), $\mathrm{Mg}$ (Figure 2b), and $\mathrm{PO}_{4}$ (Figure 2c) concentrations were unaffected. In all cases, the treatment effects and treatment $\times$ time interactions were not significant $(P>0.05)$. These results are not surprising given that $1,25(\mathrm{OH})_{2} \mathrm{D}_{3}$ concentra-
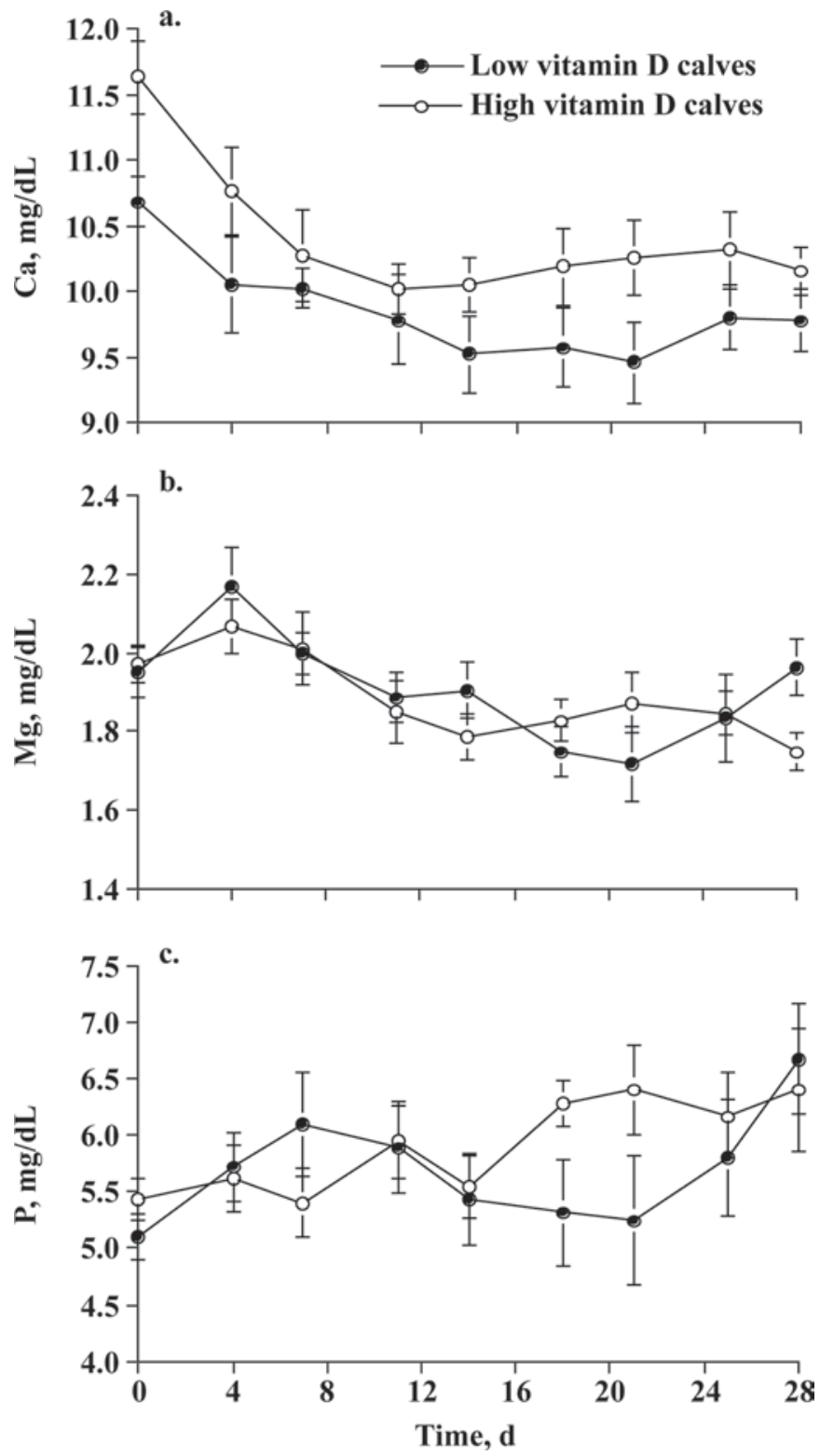

Figure 2. Plasma calcium (panel a), magnesium (panel b), and phosphorous (panel c) concentrations in preruminant calves administered 25-hydroxyvitamin $\mathrm{D}_{3}$ subcutaneously during a 28-d study period with the goal of establishing a low vitamin $\mathrm{D}$ status group $(\mathrm{n}=$ 6 ) and a high vitamin D status group $(\mathrm{n}=7)$.

tions were also unaffected by the amount of $25(\mathrm{OH})$ $\mathrm{D}_{3}$ administered. Blood $1,25(\mathrm{OH})_{2} \mathrm{D}_{3}$ concentrations were associated with blood $\mathrm{Ca}(\mathrm{r}=0.48, P<0.0001)$ concentrations (Figure 3), but not blood $\mathrm{Mg}(\mathrm{r}=0.12$, $P=0.20)$ or $\mathrm{PO}_{4}(\mathrm{r}=0.05, P=0.58)$ concentrations.

Considering all calves, blood calcium concentrations decreased $(P<0.001)$ with age and ranged from 11.2 $\mathrm{mg} / \mathrm{dL}$ on d 0 to $9.8 \mathrm{mg} / \mathrm{dL}$ on d 14, within the normal range for young calves (NRC, 2001). Blood Mg concentrations varied significantly $(P<0.0001)$ during the 


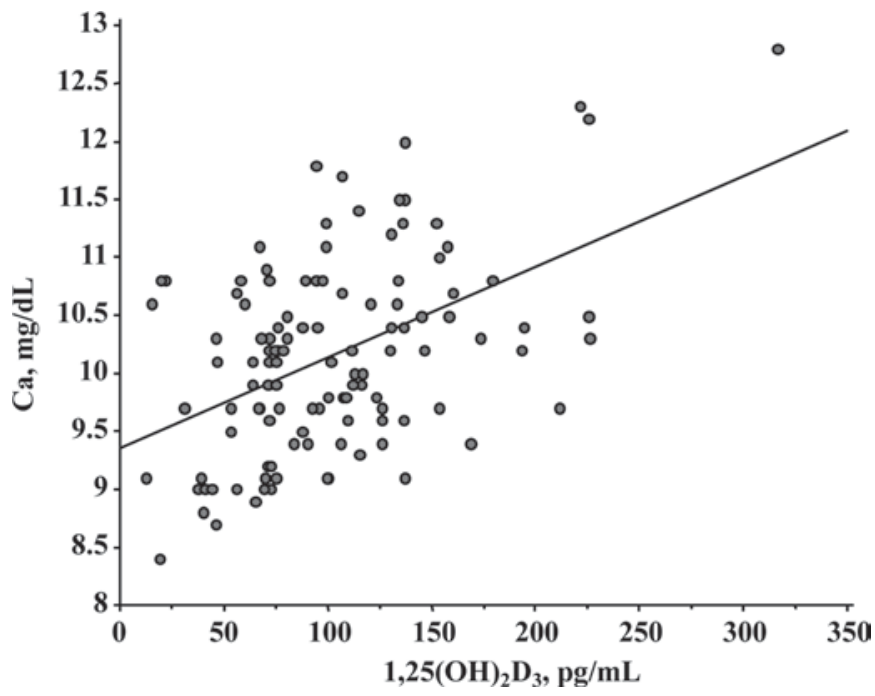

Figure 3. Regression plot describing the association between plasma 1,25-dihydroxyvitamin $\mathrm{D}_{3}\left[1,25(\mathrm{OH})_{2} \mathrm{D}_{3}\right]$ and plasma calcium concentrations in all calves during the $28-\mathrm{d}$ study period. The relationship between these variables is described by $\mathrm{Y}=193.5+29.1 \mathrm{x}, \mathrm{R}^{2}=$ $0.227, \mathrm{n}=117$.

study and ranged from $2.12 \mathrm{mg} / \mathrm{dL}$ on d 4 to $1.80 \mathrm{mg} /$ $\mathrm{dL}$ on d 18. Although a normal range for plasma $\mathrm{Mg}$ has not been established for preruminant calves, these values fall within the normal range (1.8 to $2.4 \mathrm{mg} /$ dL) for the adult dairy cow (NRC, 2001). Phosphorous concentrations in dairy cattle normally range from 4 to $8 \mathrm{mg} / \mathrm{dL}$, although this range can be higher ( 6 to $8 \mathrm{mg} / \mathrm{dL}$ ) in growing cattle (NRC, 2001). Blood $\mathrm{PO}_{4}$ concentrations for calves in the current study did not change $(P=0.11)$ with time, ranging from $5.3 \mathrm{mg} / \mathrm{dL}$ on $\mathrm{d} 0$ to $6.3 \mathrm{mg} / \mathrm{dL}$ on $\mathrm{d} 28$. Plasma macromineral concentrations in the current study are comparable to those in calves fed standard and intensified milk replacers (Nonnecke et al., 2007).

In conclusion, results indicate that vitamin $\mathrm{D}$ status of the preruminant calf can be controlled using parenteral administrations of $25(\mathrm{OH}) \mathrm{D}_{3}$. The high and low vitamin D-status groups generated using this approach, although differing with regard to plasma $25(\mathrm{OH}) \mathrm{D}_{3}$ levels, would not be considered to be outside normal ranges for either $25(\mathrm{OH}) \mathrm{D}_{3}$ or $1,25(\mathrm{OH})_{2} \mathrm{D}_{3}$. The groups also did not differ with regard to plasma $\mathrm{Ca}, \mathrm{Mg}$, or $\mathrm{PO}_{4}$ concentrations. By modifying $25(\mathrm{OH})$ $\mathrm{D}_{3}$ dosage and frequency of administration, this model could be used to examine not only the effects of vitamin $\mathrm{D}$ deficiency on mineral metabolism but also the effects of subclinical deficiency on immune regulation. Finally, these results and those from recent studies suggest that levels of vitamin D in commercial milk replacers exceed the requirements of preweaned dairy calves.

\section{REFERENCES}

Barlet, J. P., T. M. Nguyen, M. J. Davicco, C. Dardillat, J. Lefaivre, and M. Garabedian. 1981. Plasma concentrations of vitamin D metabolites in the bovine species during the perinatal period. Reprod. Nutr. Dev. 21:127-134.

Goff, J. P. 2004. Macromineral disorders of the transition dairy cow. Vet. Clin. Food Anim. 20:471-494.

Holick, M. F. 2007. Vitamin D deficiency. N. Engl. J. Med. 357:266281.

Hollis, B. W. 2005. Circulating 25-hydroxyvitamin D concentrations indicative of vitamin D sufficiency: Implications for establishing a new effective dietary intake recommendation for vitamin D. J. Nutr. 135:317-322.

Hollis, B. W.. J. Q. Kamerud, A. Kurkowski, J. Beaulieu, and J. L. Napoli. 1996. Quantification of circulating 1,25-dihydroxvitamin D by radioimmunoassay with an ${ }^{125}$ I-labeled tracer. Clin. Chem. 42:586-592.

Hollis, B. W., J. Q. Kamerud, S. R. Selvaag, J. D. Lorenz, and J. L. Napoli. 1993. Determination of vitamin D status by radioimmunoassay with an ${ }^{125}$ I-labeled tracer. Clin. Chem. 39:529-533.

Horst, R. L., J. P. Goff, and T. A. Reinhardt. 1994. Calcium and vitamin D metabolism in the dairy cow. J. Dairy Sci. 77:19361951

Looker, A. C., C. M. Pfeiffer, D. A. Lacher, R. L. Schleicher, M F. Picciano, and E. A. Yetley. 2008. Serum 25-hydroxvitamin D status of the US population: 1988-1994 compared with 2000-2004. Am. J. Clin. Nutr. 88:1519-1527.

Naito, Y., E. Watanbe, A. Oshibe, R. Sato, and D. Murakami. 1983. Plasma level of 1,25-dihydroxyvitamin D in neonatal calves. Jpn. J. Vet. Sci. 45:533-535.

NRC. 2001. Nutrient Requirements of Dairy Cattle. 7th rev. ed. Natl. Acad. Sci., Washington, DC.

Nonnecke, B. J., M. R. Foote, R. L. Horst, W. R. Waters, B. L. Miller, T. E. Johnson, and M. Fowler. 2007. Effect of growth-rate on fatsoluble vitamin, copper, and zinc concentrations in the circulation of neonatal calves. J. Dairy Sci. 86(Suppl. 1):358. (Abstr.)

Norman, A. W. 2008. From vitamin D to hormone D: Fundamentals of the vitamin D endocrine system essential for good health. Am. J. Clin. Nutr. 88:491S-499S.

Parekh, A. C., and D. H. Jung. 1970. Serum inorganic phosphorous determination using p-phenylenediamine as a reducing agent. Clin. Chem. 27:373-377.

Rajaraman, V., B. J. Nonnecke, and R. L. Horst. 1997. Effects of replacement of native fat in colostrum and milk with coconut oil on fat-soluble vitamins in serum and immune function in calves. J. Dairy Sci. 80:2380-2390.

Reinhardt, T. A., R. L. Horst, and J. P. Goff. 1988. Calcium, phosphorous, and magnesium homeostasis in ruminants. Vet. Clin. North Am. Food Anim. Pract. 4:331-350.

Salle, B. L., E. E. Delvin, A. Lapillonne, N. J. Bishop, and F. H. Glorieux. 2000. Perinatal metabolism of vitamin D. Am. J. Clin. Nutr. 71:1317S-1324S.

Steichen, J. J., R. C. Tsang, T. L. Gratton, A. Hamstra, and H. F. DeLuca. 1980. Vitamin D homeostasis in the perinatal period: 1,25-dihydroxyvitamin D in maternal, cord, and neonatal blood. N. Engl. J. Med. 302:315-319.

van Etten, E., K. Stoffels, C. Gysemans, C. Mathieu, and L. Overbergh. 2008. Regulation of vitamin D homeostasis: Implications for the immune system. Nutr. Rev. 66:S125-S134.

Waldron, M. R., B. J. Nonnecke, T. Nishida, R. L. Horst, and T. R. Overton. 2003. Effect of lipopolysaccharide infusion on serum macromineral and vitamin $\mathrm{D}$ concentrations in dairy cows. J. Dairy Sci. 86:3440-3446. 